\title{
Die Repräsentation Maria Theresias
}

Die Repräsentation Maria Theresias. Herrschaft und Bildpolitik im Zeitalter der Aufklärung. (Schriftenreihe der Österrechischen Gesselschaft zur Erforschung des 18. Jahrhunderts, Bd. 19). Eds.: Werner Telesko - Sandra Hertel - Stefanie Linsboth. Wien - Köln - Weimar: Böhlau Verlag, 2020, 558 s. ISBN 978-3-205-23181-3

Editorskému tímu v zložení Werner Telesko, Sandra Hertel a Stefanie Linsboth sa v januári 2020 podarilo sfinalizovat' a vzápätí aj vydat' rozsahom i obsahom skutočne impozantný opus, ktorý je predmetom tejto recenzie. Kniha má totiž celkovo 558 číslovaných strán (tlačených spravidla s textom $\mathrm{v}$ dvoch stlpcoch na stranu), pričom okrem úvodu a záverečných príloh ju tvorí 52 dielčích štúdií.

Ako referujú zostavovatelia v úvode publikácie, prvotný autorský tím vyplynul z úloh výskumného projektu „Herrscherrepräsentation und Geschichtskultur unter Maria Theresia (1740-1780)", riešeného v rokoch 2015 až 2018 na Inštitúte pre výskum Habsburskej monarchie a Balkánskeho priestoru Rakúskej akadémie vied (IHB der ÖAW) pod vedením univ. docenta, dr. Wernera Telesko. Riešitelia si tu dali za ciel' aplikovat' nové prístupy na výskum bohatého a žánrovo rozmanitého materiálu k výtvarnej produkcii tereziánskej éry a dospiet' tak k pokial' možno novým náhl'adom na mechanizmy produkcie rozmanitých obrazových médií pre účely vladárskej reprezentácie. Kolektív následne získal svoju internacionálnu pestrost' vd'aka zapojeniu účastníkov medzinárodnej vedeckej konferencie „Kaiserin Maria Theresia (1717-1780). Repräsentation und visuelle Kommunikation", usporiadanej Rakúskou akadémiou vied $\mathrm{v}$ dňoch 29. - 31. marca 2017. V autorskom tíme tak okrem vyššie uvedených troch autorov-editorov celkovo figuruje aj d'alších 19 mien: Wolfgang Schmale, Thomas Lau, Katrin Keller, Marina Beck, Barbara Stollberg-Rilinger, Michaela Völkel, Marian Füssel, Anna Fabiankowitsch, Johannes Pietsch, Anne-Sophie Banakas, Katja Schmitz-von Ledebur, Johannes Frimmel, Patrick Fiska, Szabolcs Serfőző, Fanni Hende, Klaas van Gelder, Christina Posselt-Kuhli, Ekaterina Skvort-

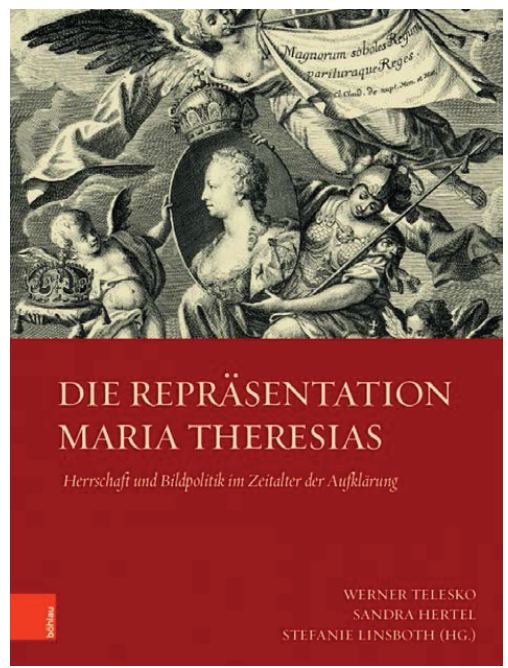

cova a Michael Yonan. Možno konštatovat', že sú medzi nimi nielen dobre známi rakúski aj mimorakúski odborníci na dejiny, umenie a vizuálnu kultúru habsburského podunajského mezoregiónu v čase panovania Márie Terézie, ale priestor k publikovaniu relevantných zaujímavých tém dostali aj noví, zatial' ešte pomerne málo známi autori a autorky.

V publikácii sú hlavné kapitoly zostavené z niekol'kých problematických okruhov tak, aby jednotlivé, do nich zaradené texty analyzovali rozmanité dôležité otázky týkajúce sa vizuálnej reprezentačnej praxe tereziánskej éry. Prvá vel'ká kapitola publikácie uvádza do problematiky skôr $z$ historického, než umeleckohistorického hladiska, vzhl'adom k čomu je nazvaná pomerne všeobecne: Herrschaft und Repräsentation. Prostredníctvom ôsmych štúdií „ukotvuje“ osobu Márie Terézie nielen v širokom kontexte Európy 18. storočia, ale rovnako aj v jej individuálnych vladárskych pozíciách $\mathrm{v}$ rámci spravovaných 
král'ovstiev, v rímsko-nemeckej ríši či v rakúskom arcivojvodstve. Väčšina autorov sa $v$ tejto časti venovala tereziánskemu mýtu (jeho genéze, logike a funkčnej stránke), respektíve ich zaujímala oblast' reálneho významu dvorského ceremoniálu v inštrumentalizácii jej vladárskej inscenácie.

Druhá hlavná kapitola knihy je venovaná tereziánskej obrazovej politike, teda všíma si umelecké formy, médiá a reprezentáciu Márie Terézie v tzv. ceremoniálnej praxi. Pochopitel'ne, k najdôležitejším prostriedkom obrazovej reprezentácie patrili podobizne, takže skladba štúdií v rámci predmetnej kapitoly je vol'ne definovaná práve rozmanitost'ou portrétnych médií a ich funkcionalitou vo sfére vladárskej propagandy. Treba skutočne ocenit', že jednotlivé texty spolu pokrývajú azda všetky možné druhy relevantných médií a ich využitie. Pre priblíženie tu možno spomenút', že podstatná čast' dielčích štúdií sa venuje napríklad tlačeným publikáciám a grafickým listom, iné zase mal'ovaným oficiálnym portrétom, portrétnym miniatúram, alebo produkcii mincí a medailí s podobizňou Márie Terézie. Nevyhýbajú sa ani problematike tereziánskej personálnej panegyriky, emblematiky, či politickej karikatúry. Adekvátnej pozornosti sa dostalo aj špecifikám portrétov Márie Terézie produkovaným pre multifunkčné komunikačné priestory radníc i tým, ktoré boli vytvárané pre slavobrány a inú efemérnu architektúru. Čast' tejto vel'kej kapitoly je venovaná vladárskej portrétnej ikonografii Márie Terézie: sú tu však precízne analyzované aj napríklad sakrálne aj mytologické identifikačné portréty Márie Terézie. Osobitnej pozornosti sa dostalo jej na mieru fabrikovanému oficiálnemu vdovskému ikonografickému typu spodobenia, pričom vel'mi zaujímavé sú aj štúdie zamerané na interpretáciu vizuálnych kódov jej verejnej i privátnej identity, obzvlášt' interpretácie vizuálnej symboliky $\mathrm{v}$ jej odevoch a gestách.

Niektoré $\mathrm{z}$ uvedených tém sú následne $\mathrm{v}$ iných kontextoch analyzované aj v tretej hlavnej kapitole recenzovanej knihy, ktorá sa raz všeobecnejšie, inokedy konkrétnejšie zameriava na aktérov obrazovej a textovej produkcie. $V$ centre pozornosti autorov dielčích textov sa tak ocitajú predovšetkým výtvarní umelci, medailéri i literáti ako realizátori týchto úloh, no rovnako si autori všímajú aj ich donátorov a zadávatelov. Treba tu spomenút' skutočnost', že okrem privátnych zadaní vladárky a jej manžela, sú $\mathrm{v}$ tejto časti reflektované aj viaceré významné objednávky zo strany štátu a cirkvi. Jednou z konkrétnych a vel'mi precízne spracovaných tém tejto kapitoly je pramenné ukotvenie viedenskej dvorskej umeleckej praxe ako výsledku vtedajších úzkych profesijných vzt'ahov medzi miestnou výtvarnou akadémiou ako „miestom profesionalizácie umenia“ a dvorom Márie Terézie ako reálnym „miestom umeleckej produkcie“. Za zmienku stojí, že Sandra Hertel tu v závere svojho textu pripojila aj prehl'adovú tabul'ku (s. 266 - 268) s menami a dátami oficiálneho účinkovania konkrétnych umelcov v dvorských službách, spracovanú na základe archívnych prameňov. Podobne dôkladne pripravil svoj text o dobových príležitostných medailách aj Patrick Fiska: pre neho však bola prameňom skúmania tematicky zameraná tlačená brožúrka z roku 1782, o ktorej sa domnieva, že anonymnou autorkou jej rukopisnej predlohy bola zrejme najstaršia dcéra Márie Terézie, arcivojvodkyňa Mária Anna.

Štvrtá čast' knihy sa konečne výraznejǔie dotýka aj nášho územia: podrobne sa totiž venuje historickým a umeleckohistorickým kontextom vlády Márie Terézie v Uhorsku. Sú tu pertraktované nielen všetky dobre známe ikonografické námety jej portrétov, vladárskych historických obrazových cyklov či medailí, ale autori sa výrazne zaujímajú o vnútorné obsahy a významy jej uhorskej politickej reprezentácie: v tomto smere napríklad podrobne analyzujú texty špeciálne pre ženu-krála (rex et domina nostra) pripravenú korunovačnú liturgiu, politické a právne aspekty ženskej vlády v Uhorsku a samozrejme, najmä špecifiká jej vizuálnej reprezentácie „na periférii““. Zopár štúdií sa, pochopitel'ne, sústred’uje aj na situáciu v Čechách, v Hornom Rakúsku i v rakúskom Nizozemí. Viacerí rakúski a mad'arskí autori vo svojich textoch $\mathrm{v}$ rámci recenzovanej knihy povšimli aj notoricky známy obrazový materiál zo Slovenska, no faktom je, že stále zostáva dost' toho, čomu sa dosial' nevenovala takmer žiadna pozornost'. Mám tu na mysli napríklad zbierky Trenčianskeho múzea v Trenčíne a najmä objekt kaštiel’a v Humennom s jeho ikonograficky zaujímavou Izbou Márie Terézie, ktoré vôbec nie sú zaznačené $\mathrm{v}$ predmetnej kapitole na mapke ,geografického rozmiestnenia portrétov Márie Terézie“" v Mad’arsku a na Slovensku (s. 354). S potešením možno konštatovat', že sa týmto témam aktuálne venuje Mgr. Martina Vysku- 
pová, interná doktorandka na Katedre dejín a teórie umenia FF Trnavskej univerzity v Trnave, v rámci svojho výskumu k dizertačnej práci.

Posledná, piata čast' knihy sa sústred’uje na komparačné rámce reprezentácie Márie Terézie s inými súdobými vladármi. Pochopitel’ne, tým hlavným objektom pre porovnávanie reprezentačných stratégií Habsburgovcov bývajú už tradične francúzski Bourbonovci. Christina Posselt-Kuhli sa zamerala na komparáciu s umeleckou politikou la gloire Ludovíta XIV. a L'udovíta XV., Werner Telesko zase na paralely a diferencie s reprezentáciou pruského vládcu. Zaujímavé porovnania vyplývajú aj zo skúmaní Jekateriny Skvortcovej ohl'adom reprezentačných stratégií dvoch vladárok: Márie Terézie a Kataríny Vel'kej. Dva finálne texty sa napokon zaoberajú vizuálnym stvárňovaním Márie Terézie v súdobom Dánsku, Švédsku Rusku (Michael Yonan), ale aj generalizujúco, sledujúc „domáce“ habsburské reprezentačné tradície (Werner Telesko).

V recenzovanej publikácii je nutné vyzdvihnút' bohatú obrazovú prílohu, ktorej podstatná čast' (175 farebných i čierno-bielych, často plnostranových ilustrácii) je prakticky umiestnená priebežne do textov a d’alších 35 ilustrácií je situovaných za posledným textom ako samostatná príloha. Ohromný je aj záverečný zoznam prameňov a literatúry, ktorý $\mathrm{v}$ dvoch stĺpcoch na stranu zaberá až 65 strán (s. 482 - 546). No nielen množstvom zohl'adneného obrazového a písomného pramenného materiálu, ale práve internacionálne a tematicky široko, no pritom vel'mi erudovane zostaveným kolektívom má táto publikácia vysoký potenciál nielen zaradit' sa, ale dlhodobo sa udržat' ako jeden zo základných, materiálovo i teoreticky aktuálnych titulov $\mathrm{v}$ rámci literatúry venovanej (nielen výtvarnému) umeniu tereziánskej éry.

Ingrid Halászová

doc. Mgr. Ingrid Halászová, PhD.

Katedra dejín a teórie umenia Filozofická fakulta TU v Trnave Hornopotočná 23 SK-918 43 Trnava e-mail: ingrid.halaszova@truni.sk 